\title{
Sinetron Indonesia Menuju Perkembangan Sebagai Sarana Media Massa
}

\author{
Bunyamin \\ Institut Pesantren KH Abdul Chalim Mojokerto \\ Aminbunyaminamin876@gmail.com
}

\begin{abstract}
Soap ope ras, better known as electronic cinema or teledrama, play a major role in society in understanding this real or real life and plugging in frames / images of thought in the future. In preparing for a global era and an increasingly advanced industrial society and intense competition in the global market, Indonesian soap operas must be able to play its role. Along with the increasing number of private TV sets, quantitatively Indonesian soap operas experienced a very proud development and also gave a variety of nuances, however the quality of Indonesian soap operas has only recently developed. Indonesian soap operas must consider the elements of education, entertainment, the real problems of society and the way they are done, such as the DKI reborn Warkop film which has a classic feel but is still interesting as a television broadcast that is comedy and educating. Actually, if we want to emulate a very educational cartoon film such as Upin and Ipin, Shiva even though the results of neighboring state products contain a message of education and a very high moral message, Indonesian children love cartoon films like this, besides being funny, educating, raising local culture, and introducing the name of a particular place. Indonesian television shows are still dominated by shows that are beyond human reach. How much television is still mystical like in the Antv program, almost every day cannot be separated from mystical shows (Eyes of the Dark, Penetrating the inner eye, GGS and others).
\end{abstract}

Keywords: Indonesian soap opera towards development

\section{Pendahuluan}

Sebelum kita membahas lebih lanjut, ada baiknya kita renungkan akankah sinetron Indonesia mengalami nasib yang sama dengan dunia perfilman kita? Sungguh ironis jika setiap rumah produksi tidak sampai menjadi sinetron di negeri sendiri. Hal ini akan menjadi semakin buruk jika mereka yang terlibat (production house), pemasang iklan, pihak televisi, saling menuduh sebagai biang keladi. Seiring bergantinya zaman dengan hadirnya televisi swasta di Indonesia, dunia persinetronan Indonesia secara kuantitatif mengalami peningkatan yang pesat. Fenomena ini dapat kita amati dari progrm masing-masing stasiun televisi yang setiap harinya tidak kurang dari 3 sampai 4 judul sinetron Indonesia ditangankan. Bahkan proses produksi dapat dipercepat. Sebagaimana contoh Garin Nugroho : sinetron Gantteng Ganteng Srigala satu seri dapat diproduksi dalam tiga hari. Misteri Gunung Merapi versi baru memerlukan waktu empat hari, Dunia Daras mampu dikerjakan dalam waktu satu hari. ${ }^{1}$ Kondisi ini didukung oleh tumbuhnya rumah produksi dimana sinetron adalah salah satu produk andalan. Pada saat ini stasiun-stasiun televisi swasta memang belum banyak menghasilkan karya sinetron. Selain besar dana pembuatan sinetron, juga konsentrasi tinggi serta sumber daya manusia yang masih rendah.

Disatu aspek pertumbuhan sinetron Indonesia memang sangat memuaskan sehingga mampu memberikan nuansa pada perkembangan televisi swasta di Indonesia. Secara kualitas dan objektifitas memang belum ada metode tau ukuran yang jelas dan pasti dalam membuat sinetron yang baik dan berkualitas serta memenuhi selera pemirsa. Semua

\footnotetext{
${ }^{1}$ Nugroho G, Kekuasaan dan Hiburan, Yayasan Bentang Budaya (Yogyakarta: 1995), hal. 120
} 
masih relatif dan semua tergantung penilaian setiap penonton. Mempertemukan dua unsur yakni selera pemirsa dan isi pesan sinetron memang suatu pekerjaan yang berat. Meskipun hal tersebut menjadi garapan besar namun tetap harus dicarikan solusi agar sinetron di Indonesia tidak hanya kuantitas saja tetapi kualitas psikologis tontonan.

Salah satu paket siaran broadcast televisi, sinetron dapat memadukan fungsi televisi sebagai media komunikasi massa yaitu memberikan informasi, pendidikan, dan hiburan. Menurut kuswadi ada beberapa hal yang harus diperhatikan dalam membuat sinetron, yaitu isi pesannya sesuai dengan realitas sosial pemirsa, mencerminkan tradisi nilau luhur dan budaya masyarakat, dan lebih banyak mengankat persoalan yang terjadi dalam kehidupan masyarakat. $^{2}$ oleh sebab itu logika alur cerita harus diperhatikan untuk memperkuat kreatifitas dan daya imajinasi.

Apabila kita memperhatikan sinetron Indonesia dari aspek kualitas masih sangat memprihatinkan. Tema-tema yang diangkat sinetron kembali pada kondisi masyarakat agraris seperti cerita hantu, dan kekuatan magis benda kuno. Contohnya Jodoh W asiat Bapak, Indra ketuju, Mata Batin (AnTv), Ingat ada azab (Indosiar), Sepatu Super (RCTI), Tuyul dan mbakyul (AnTv), anehnya hal seperti ini menjadi trend pada semua stasiun televisi di negeri ini yang tidak sejalan dengan perkembangan bangsa Indonesia yang memasuki masyarakat industri dan menghadapi era pasar bebas. Menurut Veven Wardhana, sinetron Indonesia masih menduduki sinetron interior atau kedudukan sinetron sendiri masih dalam kapasitas subordinasi terhadap iklan. ${ }^{3}$

Tulisan artikel terkait judul penelitian "Sinetron Indonesia menuju perkembangan sebagai sarana media massa" berusaha mengungkap bagaimana tingkat kualitas sinema elektronik di Indonesia pada masa dewasa ini.

Penulis berusaha mengungkap mengapa kualitas sinetron Indonesia masih rendah, sehingga ditemukan solusi untuk memberdayakan sinema elektronik Indonesia bisa benarbenar menjadi tuan rumah di negeri sendiri.

Tulisan berikut Sinema elektronik Indonesia menuju perkembangan sebagai sarana media massa menggunakan pendekatan kualitatif. Patton berpendapat metode kualitatif dapat digunakan untuk memahami gejala-gejala atau fenomena yang terjadi secara alamiah ${ }^{4}$. Dengan menggunakan metode kualitatif data yang diperoleh akan lebih kredibel, akurat, dan lebih lengkap sehingga penelian yang di inginkan dapat tercapai denga maksimal.

Sedangkan jenis penelitian ini adalah deskripsi. Sebagaimana penjelasan Jalaluddin Rahmat, metode deskripsi dititik beratkan pada observasi dan suasanaalamiah (naturalistis setting). ${ }^{5}$ Denagan suasana alamiah dimaksudkan bahwa peneliti terjun kelapangan mengobservasi serta mencatat variabel-variabel yang ada. Penelitian deskripsi mungkin terlahir karena kebutuhan karena yang diteliti menarik perhatian peneliti sedangkan kerangka teoritisnya belum ada.

Jadi dapat disimpulkan penelitian deskripsi merupakan penelitian kualitatif yang meneliti variabel beruapa suasana alamiah, dipelajari, menggambarkan, menganalisa dan menafsirkan pola perfilman yang ada di Indonesia.

\section{Pembahasan}

\section{Hakekat Sinetron (Sinema Elektronik)}

Televisi adalah sebuah media untuk menyampaikan pesan yang bersifat audiovisual. McLuhan mengungkapkan melalui ungkapan yang kontrofersi

\footnotetext{
${ }^{2}$ Kuswadi W, Komunikasi Massa: Sebuah Analisis Media Televisi, Rineka Cipta: Yogyakarta: 1996), hal 130

3 Veven Wardhana, Kapitalisme Televisi dan Stategi Budaya Massa, (Yogyakarta: Pustaka Pelajar” 1997), hal 261

${ }^{4}$ Rulam Ahmadi, Metodologi Penelitian Kualitatif, (Yogyakarta : Ar-Ruzz Media, 2014), hal 15-16

${ }^{5}$ Rahmat Jalaluddin, Metode Penelitian Komunikasi, (Bandung: PT. Rosda Karya, 2000), hal 24-25
} 
mengenai makna media, ia memaknai media dengan pesan itu sendiri. ${ }^{6}$ (the medium is the message). Adakalanya masyarakat lebih tertarik dari media dari pada pesan itu sendiri seperti orang mengirim pesan lewat facebook, atau email bisa jadi yang lebih menarik karena memakai internet sebagai media. Begitu pula daam dunia perfilman orang lebih tertarik film dibandingkan sinetron.

Masyarakat pada umumnya lebih mengenal film daripada sinetron. Katakata sinetron akan di kenal oleh masyarakat apabila dalam tayangan tersebut mencantumkan kata sinetron. Perlu diketahui bahwa anatara keduanya sangatlah berbeda dari produksinya, penayangannya, serta dalam penikmatan yang dilakukan oleh masyarakat.

Sinetron merupakan nama lain dari teledrama, sandiwara televisi, lakon televisi. Persamaan keduanya terletak pada sama-sama di tayangkan melalui medium audio visual yang disebut televisi. Dari kesekian sebutan sinetron adalah ungkapan yang lebih umum ditelinga masyarakat umum.

Sinetron merupakan kepanjangan dari sinema dan elektronik. Dalam hal ini Veven sp Wardhana memberikan definisi sinetron bahwa elektronik disini tidak semata mengacu pada pisa kaset rekaman film, tetapi lebih mengarah pada medium penyiarannya yaitu televisual yang merupakan medium elektronik bukan medium radio.

Ciri khas televisi dan film sebagai media komunikasi massa sangat bereda dalam proses pengambilan gambar. Pengambilan gambar televisi cukup menggunakan kaset video lalu disiarkan lewat stasiun televisi kemudian dapat dinikmati tayangannya di setiap rumah. Sedangkan perfilman proses pengambilan gambar filmnya melalui kamera kemudian dicuci di laboratorium, kemudian proses dubbing kemudian baru dapat diproyeksikan ke layar lebar di ruangan ynag gelap. Perbedaan karakter ini memberi pengaruh besar terhadap audien atau penonton.

Perbedaan karakteristik daya pengaruh sinematelevisi tersebut sangat berbeda dengan daya pengaruh film layar lebar atau lebih populer dengan sebutan bioskop. Sinetron disajikan untuk masyarakat umum naumn dapat menyelesaikan perkerjaan lain saat jeda iklan, sedangkan layar lebar dihadapkan lulus pada posisi layar yang lebarnya kurang lebih $6 \mathrm{~m}$ dan dalam keadaan ruangan yang gelap gulita tanpa dapat melakukan aktifitas lainnya sehingga dalam menikmati tayangan film benar benar fokus dan effect psikologis juga sangat menikmati.

\section{Trend Spin Off}

Kegiatan meniru sama aslinya tanpa seijin dengan tujuan bisnis merupakan pelanggaran hak cipta yang ada hukuman pidananya. Namun apabila penjiplakaan kreatif bukan disebut plagiat yang merupakan jalan keluar memanfatkan keberhasialan dengan kreatifitas baru sebagaimana Jepang contoh konkritnya. Jepang menjadi negara maju berkat kepiawaian warganya dalam meniru kreatifitas orang lain. Pola tradisi seperti ini merupakan suatu hal yang tak terpisahkan dalam dunia pertelevisian yang dikenal dengan Spin Off. Spin off adalah meniru unsurunsur dari sebuah satuan mata acara yang lebih terbukti kesuksesannya.

Dalam kerja meniru tersebut terdapat ide-ide kreatif seperti meneruskan, memperluas, mengembangkan yang di masukkan kedalam proses pembuatan film atau sinetron terseb ${ }^{7}$ ut. Atau mengembangakan segmen pasar baru dengan

\footnotetext{
${ }^{6}$ Morissan, Teori komunikasi individu hingga Massa, (Jakarta: Prenada Media Group), 2013, hal 493.

${ }^{7}$ Ibid, hal 450 .
} 
memposisikan pada tempat yang lebih tepat. Dengan pola kerjasa seperti ini dapat memperkecil resika plagiatis, karena pasar telah dikuasai terlebih dahulu. ${ }^{8}$

Secara ekonomis, kegiatan semacam ini wajar-wajar saja saling berlombalomba menguasai udara dan penonton. Stasiun penyiaran pun tidak dapat menghentikan kegiatanya meskipun sebentar akibat kekurangan atau keterlambatan satuan acara.

Trend spin off ini memang mujarab guna memenuhi kerja efektif dan efisien bagi suatu stasiun pertelevisian. Bukti nyata kebudaan spin off tersebut sering tidak menjadi pengolahan unsu-unsur yang ditiru secara kreatif. Padahal pesan kreatif peniruan adalah jika peniru memahami apa yang di wakili inovasinya dripada yang ditirunya.

Dalam proses pertumbuhan televisi dewasa ini menurut Garin Nugroho, keseragaman justru tidak memperluas segmen khalayak dan iklan itu sendiri bahkan melahirkan grafik perhatian yang cenderung merosot. ${ }^{9}$ Dalam dunia perfilman di Indonesia juga tidak jauh beda dengan kenyaataan diatas yakni budaya spin off. Sebuah sinetron yang mempunyai rating tinggi akan menjadi rumah produksi beramai-ramai meniru, bahkan siaran staisiun televisi pun berlomba-lomba untuk menayangkannya seperti sinetron mermaid, GGS, Misteri Gunung Merapi, tujuh Manusia harimau, jodoh wasiat bapak, dan misteri Ilahi. Sinetron ini kemungknan yang menyebabkan khalayak penonton yang menjadi bosan.

3. Kedudukan Iklan terhadap Sinema Elektronik di Indonesia

pada umumnya sinetron membutuhkan waktu jeda yang lama dalam setiap plot dan ritmenya. Dari jeda inilah rumah produksi dan syuting dalam pertelevisian mendapatkan keuntungan yang sangat besar, selain memberikan kesempata pada pemirsa menyelesaikan tugas juga memberikan jeda efek spikologis pada penonton. Pada waktu jeda ini juga diberikan tayangan yang dapat menguras emosi seperti iklan.

Pembuatan sinetron pada akhirnya mengurangi kualitas perfilman karena dipengaruhi oleh kepentingan periklanan. Contoh sinetron jodoh wasiat bapak, GGS, awal mulanya memuat iklan hanya sedikit tetapi lama - lama anatara iklan dan tayangan sinetron lebih banyak iklan yang mensponsori setelah berjalan beberapa episodenya.

Menurut Rachmawati seabagaimana yang dikutip oleh Yulia Yasmasari, saat ini media televisi dijadikan sebagai media utama kegiatan promosi terhadap produkproduk barang maupun jasa, baik dari promosi yang dilakukan sebuah perusahaan barang maupun promosi dari stasiun itu sendiri. Televisi menyampaikan pesan audio visual yang memungkinkan pesan terkesan secara nyata sehingga memberikan gambaran real kepada khalayak masyarakat sebagai calon konsumen dari produk tersebut. ${ }^{10}$

Dalam dunia bisnis sintron telah dicommercilkan dan iklan tetap menduduki rating yang pertama dan utama. Ada televisi yang menayangkan film bagus namun tanpa jeda iklan maka stasiun televisi tersebut menjadi sepi oleh production house pada akhirnya juga tidak diminati lagi oleh pemirsa seperti TVRI. Sinetron digunakan sebagai alat kail untuk memancing iklan guna meraup keuntungan besar karena iklan menjadi urat nadi dan alat pernafasan pertama dan

\footnotetext{
${ }^{8}$ Nugroho, Kekuasaan Dan Hiburan, (Yogyakarta: Yayasan Bentang Budaya, 1995), hal 112-119.

${ }^{9}$ Ibid, hal 112.

${ }^{10}$ Suraya, Yulia Yasmasari, Jurnal Prosiding Konferensi Nasional Komunikasi, Vol, 01, No. 01, 2017, hal 5.
} 
utama dalam kelangsungan kehidupan pertelevisian kecuali TVRI karena TVRI merupakan televisi negara segala tayangan dan siaran dibiayai oleh pemerintah pada tahun 2000 an.

Pada saat ini TVRI juga telah mempunyai daya saing dengan televisi- televisi swasta dalam menayangkan acara televisi, hal ini terbukti TVRI juga memasang iklan namun bukan seagai urat nadi dan pernafan utama untuk kelagsungan hidup stasiun televisi, tetapi lebih dari sebagai pembenahan alat komunikasi dan penataan ulang stasiun dan ruang syutung serta penataan ulang kinerja karyawan yang membutuhkan dana yang luar biasa yang tidak mungkin di cover oleh semua oleh pemerintah.

Dalam satuan acara TVRI juga bersaing dengan televisi televisi swasta dalam menayangka siaran televisi untuk mendapatkan pemirsa dan untuk mengembalikan citra dunia pertelevisisan yang tayangannya hanya melulu berita saja akan tetapi juga menayangkan hiburan dan juga sinetron dan film layar lebar.

Tingkat rating merupakan indikator penayangan siaran pertelevisian. Sebuah tayangan atau sinetron yang mendapatkan rating tnggi ia akan laku keras dan mahal untuk diklankan. Ukuran rating menjadi penyebab production house kurang percaya terhadap persinetronan, sehingga sinetron dibuat serial dan jarang di produksi secara genus sinetron atau layar lebar.

Kekuatan iklan terhadap kreatifitas dunia persinetronan Indonesia merupakan buah simalakama yang sedang menghadang. Disatu pihak komersial yang ekstrim dan dipihak lain idealis terlalu tinggi.

Salah satu penawaran solusinya adalah sinetron benar -benar dijadikan pemilik penonton agar penonton mersa memiliki dan bertanggung jawab terhadap sinetron yang ditayangkan makarating sinetronpun akan tinggi rumah produksi pun akan saling percaya aatas kualitas Indonesia serta periklanan dan persinetronan pun berusaha tidak hanya bergantung pada rating semata juga memperhatikan kualitas perfilman Indonesia.

Perbedaan Sinema Elektronik (Sinetron) dan Layar Lebar ${ }^{11}$
Kategori
Sinema Elektronik (Sinetron)
Film Layar Lebar

1. Proses Produksi Kamera video dengan kaset video, editing.

2. Penyampaian

Disiarkan oleh stasiun televisi pemancar, diterima pesawat penerima setiap rumah dan tidak bergantung pada ruang gelap/bioskop

3. Jeda pencahayaan

Kamera dengan pita seluloid, proses laboratorium, dubbing

Menggunakan mesin proyektor, menggunakan layar lebar dan menggunakan Adajeda untuk memungkin Tidak ada jeda pemirsa menyelesaikan pekerjaannya. Jeda ini biasa diisi oleh iklan yang disebut commercial break

4. Penonton

- Heterogen

- Konsentrasi rendah
- Homogen

- Konsentrasi tinggi

11 Basuki, Sinetron Indonesia Antara pertumbuban dan kecemasan, Jurnal Paradigma Vol I, No. 4, Desember 2017, (Yogyakarta: FISIPOL UPN “Veteran”), hal 5. 
- Tidak terkondisikan (sambil masak, baca majalah dll)

5. Effek

6. Macam
- Lebih rendah

- Sinema serial

- Senema lepas

- Senema miniseri
- Terkondisikan

(semua anggota tertuju pada layar lebar)

- Lebih tinggi

- Film seri

- Film lepas

4. Tema dan Alur Cerita sinetron indonesa

Sebuah sinetron akan selalu mendapatkan pemirsa bahkan pemirsa merasa memiliki serta ikut menjadi bagian dari sinetron tersebut jika tema dan alur cerita memenuhi psikologis tontonan. Tema menurut poerwodarminto adalah pokok pikiran. Tema harus dibedakan antara niai moral dan amanat. ${ }^{12}$ Sedangkan alur merupakan jaan ceritayang dimulai dari perkenalan, awal masalah, menuju klimaks, klimaks dan solusinya. ${ }^{13}$ Dalam arti efektifitas dan efesiensitas suatu cerita meliputi unsur keindahan dan logis dalam kehidupan manusia. Sinetron yang alur dan tema ceritanya tidak memenuhi keduanya akan menjadi tontonan yang semu semata. Oleh karena itu produsen, sutradara, harus dapat mengakat alur dan tema cerita sinetron dari kehidupan nyata.

Indonesia tergolong negara yang warga negaranya mayoritas menengah kebawah dan syarat dengan permasalahan- permasalahan. Lebih sesuai jika alur dan tema cerita sinetron di angkat dari kehidupan nyata masyarakat Indonesia yang syarat dengan permasalahan - permasalahan beserta jalan keluarnya, banyak sekali permasalahan masyarakat yang belum terangkat untuk mendapatkan pemecahan jalan keluarnya dari kesulitan hidup selain juga memberikan hiburan kepada masyarakat.

Bila kita cermati sinetron dan film Indonesia mempunyai alur dan cerita yang kurang fokus dikarenakan episode yang terlalu panjang sehingga satu tokoh utama tidak diceritakan keberadaannya, apakah merantau, mati, dan lain sebagainya tidak diceritakan seakan menjadi tanda tanya besar di hati pemirsa. Contoh Tukang bubur Naik. Haji, Bayi yang tertukar, tukang ojek, pengkolan. Sinetron ini pada awalnya sangat menarik dan mendapat ruang dihati pemirsanya, tetapi karena episode yang begitu banyak hingga 2000 episod (TBNH), (TOP) 1000, bayi yang tertukar hingga 800 an episodnya yang tak kungjung usei alur ceritanya membuat kalangkabut penggemarnya lagi pula dalam alur cerita tukang bubur tidak dijelaskan kemana pergi tukang buburnya, meninggalkah atau merantau kemudian yang sesuai dengan alur judul film sudahkan tukang buburnya naik haji????? Tidak konsisten!!!!!

Salah satu tayangan yang masih konsisten terhadap permasalahan ini adalah stasiun TVRI dan Indosiar dengan sinetron inem pelayan seksi yang mencoba mengakat permasalahan kaum dhuafa atau pembantu. Sinetron ini menjadi sebuah solusi yang mungkin sulit ditiru oleh pembantu yang lain. Apakah pembantu akan terangkat hidupnya apabila telah mendapatkan fasilitas yang mewah seperti menjadi istri manajer atau bahkan istri seorang juragan. Meskipun demikian sinetron ini memberikan kontribusi yang baik bagi masyarakat menengah keatas agar tidak

\footnotetext{
12 Poerwodarminto, W,J,S, Kamus Umum Bahasa Indonesia, (Jakarta: Gunung Agung) 1971, hal. 1040

13 Teti Milawti, penngkatan kemampuan anak memahami drama dan menulis teks dranma melalui pembelajaran SAVI, Jurnal Edisi khusus,no 2 ,Agustus 2017, hal 20.
} 
menganggap pembantu adalah sampah masyarakat. Bukan tidak sopan jika seorang manager menjadikan pembantu yang tergolong kelas menengah kebawah di jadikan sebagai pendamping hidupnya.

Sinetron AAI (Aku Anak Indonesia) adalah sinetron yang tayang di RCTI dimulai pada 5 Aprl 2015. Sinetron Aai mengandung unsur kepribadian anak dan remaja,seperti bertanggug jawab, kerja keras, disiplin, kerjasama, saling menghormati, menghargai, bersaing dengan sehat, persahabatan, dan sikap positif. Sinetron AAI ini tidak jauh beda dengan sinetron ACI (Aku Anak Indonesia) pada tahun 80 an yang ditayangkan oleh stasiun TVRI pada saat itu. Kedua sinetron tersebut juga bisa berarti singktan dari ketiga tokoh utamanya dalam sinetron Aci tokoh tamanya yaitu Amir (agyl Syahriar), Cici (Dyah Ekowati Utomo), dan Ito (Ario Sagantara). Sedangkan dalam sinetron AAI tokoh utamanya yaitu, Ani (Dinda Hauw), Arif (Giorgino Abraham), Ito (Dante Valreand). ${ }^{14}$

Film warkop DKI reborn 'Jangkrik Boss" merupakan sebuah hasil karya yang patut di kembangkan, disamping menghibur juga alur ceritanya dapat serta ada unsur mendidik. Film warkop DKI ini melibatkan masyarakat umum dan syutingnya di ruangan lepas sebagai pengobat rindu film warkop DKI yang lama hilang karena pemainnya yang sudah tiada. Film ini memberikan nuansa baru bagi masyarakat luas pesan komedian seorang petugas keamanan yang jujur namun penuh masalah karena sikap konyolnya. "jangkrik Bosss" part 2 banyak syuting di Malaysia tepatnya di Kuala Lumpur karena sutradaranya berharap dengan syuting di luar akan mendapatkat suasana yang lebih fresh dan dapat membandingkan latar yang ada di negara sendiri maupun diKuala Lumpur.

Pada umumnya sinetron Indonesia mengangkat kehidupan menengah atas. Tema yang diusung pun berkisar seputar permasalahan percintaan antara laki= laki dan perempuan, atau balas dendam sehingga melahrkan adegan- adegan kekerasan dan banyak ditiru oleh anak- anak dan juga para remaja . tampaknya sutradara Indonesia banyak mengadopsi telenovela dan film barat yang terbukti sukses kemudian di sinetronkan. Tetapi masih banyak yang dapat diambil pelajaran dibalik kehidupan glamournya para artis telenovela dan sinetron barat yaitu tentang korupsi, kesombongannya, otoriternya ataupun yang lainnya.

Tidak sedikit sebenarnya permasalahan - permasalahan yang dihadai oleh masyarakat Indonesia untuk mendapatkan apresiasi dan jalan keluarnya. Seperti kehidupan tuna wisma yang sukses, kehidupan kupu- kupu malam, lika- liku seorang divabel dan lain lain.

Permasalahan yang layak diangkat menjadi tema dan alur cerita sinetron sangatlah banyak dan tidak akan habis digali. Disamping bersumber dari kehidupam mmasyarakat yang nyata dan dapat diamati ada juga sumber yang tertulis seperti novel, cerpen, essay yang berkualitas dimana masyarakat menunggu untuk di angkat menjadi sebuah sinetron.

Untuk mendapatkan tema dan alur cerita sinetron yang baik dibutuhkan rasa empati yang dalam terhadap masalah masyarakat yang nyata. Kemampuan menangkap suasana dan psikologis penonton pasti menghasilkan acara yang tidak hanya enak ditonton tetapi juga dinikmati. Hal ini tidak jauh berbeda dengan prinsip komunikasi, bahwa proses komunikasi akan berjalan lancar bilaman masingmasing pihak mampu merasa empati terhadap lawannya atau komunikan ${ }^{15}$.

\footnotetext{
14 Suraya, Yulia Yasmasari, Jurnal Prosiding Konferensi Nasional Komunikasi, Vol, 01, No. 01, 2017, hal 67.

15 Stanley J. Baran \& Dennis K. Davis. Mass Comunication Theory (Foundations, Ferment, and Future: Sixth Edition), 2015, hal 324.
} 
Dengan demikian pembuatan sinetron Indonesia disamping di angkat dari kehidupan masyarakat yang nyata, juga tidak terlalu banyak episode. Episode yang terlalu banyak akan menimbulkan ketidak fokusan pada alur cerita yang sesuai tema awal. Oleh karena itu ada beberapa hal yang perlu di perhatikan dalam pembuatan sinetron Indonesia adalah:

a. Judul

Sayogyanya judul yang di pakai harus semenarik mungkin, sehingga penonton akan merasa penasaran dan sangat antusias untuk segera di tayangkan di stasiun televisi. Juga diharapkan dengan adanya judul tersebut dapat dijadikan sebagai pembatas ruang alur cerita hingga penutupan sinetron, jangan sampai alur cerita keluar dari garis besar judul yang ada sehingga menimbulkan ke-bosanaan di benak pemirsa dan pindah channel lain sebelum alur cerita selesei. Sebagaimana sinetron Tukang Bubur Naik Haji episode terbanyak hingga 2000 episode lebih. Hal ini dapat menjadikan ketidak fokusan alur cerita dan bahkan alur cerita yang seharusnya ada justru hilang karena pergantian pemain.

Berbeda dengan sinetron ACI dan AAI, judul sederhana dan saling berkaitan dengan tokoh utamanya. Kedua sinetron ini mengisahkan kehidupan kaum remaja yang memiliki idealisme yang dapat mengatasi permaslahan orang orang disekitar, mereka orang egoias yang tidak mempedulikan nasib bangsa, dan juga mengajarkan tentang kehidupan dan kegiatan positif yang seharusnya dilakukan oleh remaja. ${ }^{16}$

b. Karakter pemain

Karakter adalah sifat atau watak yang muncul dalam diri seorang tokoh. ${ }^{17}$ Pemain sinetron yang muda ganteng dan juga cantik merupakan nilai sendiri dimata penggemarnya. Sinetron yang mempunyai pemain yang rupawan akan menjadi idola di setiap gerak pemirsa. Namun pemain yang ganteng dan cantik saja tidak cukup dalam dunia sinetron. Alangkah baiknya antara karakter dan pemain dapat diserasikan jangan sampai terlalu di paksakan. Antara pemain muda berperan sebagai orang tua atau sebaliknya sehingga tidak terjadi kejanggalan. Karakter pemain merupakan jantung sebuah sinetron jika salah menempatkan pada posisi yang kurang tepat maka sudah membuyarkan rasa psikologis penonton.

Sinetron Indonesia juga harus dapat merekrut para pemain yang rupawan dan juga berkarakter. Jangan hanya menggunakan satu artis yang lagi booming kemudian dipaksakan karakternya sehingga dapat mengurangi nilai sebuah sinetron .

c. Latar

Latar adalah suasana tempat atau background sebuah drama atau sinetron. Dalam jurnal kajian sastra bahasa dipaparkan lata (setting) adalah tempat terjadinya peristiwa dalam cerita atau lingkungan yang mengelilingi pelaku. ${ }^{18}$ Latar sebaiknya disesuaikan dengan judul sinetron. Jika sinetron yang berbau sejarah kerajaan misalnya maka latar yang digunakan adalah hutan, kerajaan, kuda, sapi, delman kostum

\footnotetext{
${ }^{16}$ Suraya, Yulia Yasmasari, Jurnal Prosiding Konferensi Nasional Komunikasi, Vol, 01, No. 01, 2017

17 Teti Milawti, Penngkatan kemampuan anak memahami drama dan menulis teks dranma melalui pembelajan SAVI, Jurnal Edisi khusus,no 2 ,Agustus 2017. Hal 45.

${ }^{18}$ Jurnal Kajian Bahasa sasra dan pengakaran (KIBASP), 2 (1)- 2018, hal 96:105.
} 
zaman dahulu, dll kemudian penampilan artisnya pun tidak jauh dari keadaan nyata pada masa kerajaan tersebut. Tidak berpenampilan dengan baju zaman sekarang make up yang berlebihan dan lain sebagainya karena semua itu tidak mencerminkan keadaan pada zaman dahulu, begitu juga asosoris yang digunakan mencerinkan masa lalu. Contoh sinetron Gunung Merapi, Raden Kian Santang, angling Darma

d. Properti

Apabila sinetron Indonesia ingin bersaing dengan drama -drama luar maka jangan tanggung tanggung dalam menggunakan properti, jangan selalu properti dalam sinetron selalu diimitasi jauh dari aslinya Dan ini yang dapat menurunkan nilai perfilman. Jika film atau sinetron mempunyai alur cerita sejarah maka produsen dan sutradara harus menggunakan properti aslinya, hutan, gua, bebatuan, kerajaan dan lain sebagainya. Jangan selalu properti yang terbuat dari stereofoam yang riang mudah pecah dan tidak berbobot. Pada sinetron misteri gunung merapi, angkling darma, keluarga cemara merupakan salah satu contoh sintron- sinetron yang menggunakan properti dan latar yang asli bukan manipulasi. Sutradara maupun production house dapat menggunakan tempat, gua maupun hutan sebagai latar sekaligus memperkenalan kepada dunia sebagai tempat wisata yang bersejarah.

Pada film joshua oh joshua yang jojo diperankan oleh joshua suherman dan jejen oleh mega Utami, dua anak jalanan yang harus mencari uang setelah pulang sekolah. Mereka pergi kepusat perbelanjaan untuk menamen atau membantu membawakan barang belanjaan. Mereka tetap riang dan bernyanyi sambil berlari -lari, atau saat menyembunyikan hasil kerjanya dikaleng kemudian dikubur didalam tanah. Singkat cerita jejn mempunyai ibu kandung sedangkan jojo tidak punya ibu karena sejak kecil ia telah ditinggalkan ibunya di sebuah tempat gunang barang bekas hingga ahirnya bertemu kembali dengan kedua orang tuanya. Film ini mengambil latar dan properti yang asli dan syutingnya di tempat perbela njaan dan ruang terbuka.

5. Memberdayakan Sinetron Indonesia

Memberdayakan adalah membumikan sinetron Indonesia menjadi diri sendiri di rumah sendiri. Sinetron harus mampu memberikan nuansa tersendiri seiring dengan berkembangya televisi swasta yang lebih bersifat komersial. Dengan demikian televisi dan siaran televisi Indonesia benar-benar dirasakan menjadi milik warga dan bangsa Indonesia dan buka sekedar televisi asing yang didirikan di Indonesia (disebabkan seluruh tayangan dan satuan acaranya bermuatan import).

Bukan hanya insan sinetron (kru yang terlibat pembuatan sinetron) semata yang bertanggung jawab terhadap pemberdayaan sinetron Indonesia tetapi masyarakat sinetron juga mempunyai andil dalam menyebar luaskan sinetron tersebut. Mereka terdiri dari broadcast televisi, production house, pemirsa, pihak pemasang iklan, dan pemerintah. Produser bertanggung jawab pada alur cerita dan tema senetron yang berkualitas, stasiun televisi bertanggung jawab atas penayangan, pihak iklan juga tidak sekedar mendasarkan pada rating film atau sinetron semata, pemirsa yang kritis terhadap tayangan stasiun televisi, pemerintah juga tidak seenaknya melakukan sensor. Apabila semua unsur telah berdiri pada prinsipnya masing-masing sinetron Indonesia dapat dipastikan dapat menembus pasar luar 
negeri minimal negara serumpun (malaysia, singapora, brunei darussalam dan lainlain)

Tidak menutup kemungkinan sinetron Indonesia akan menjadi komoditi primadona dari setiap stasiun televisi. Sinetron Indonesia tidak hanya sekedar mewarnai stasiun acara televisi yang ada, tetapi lebih dapat masuk pada layar emas (satuan waktu yang ratingnya sangat tinggi). Oleh sebab itu, insan sinetron Indonesia harus mampu menciptakan sinetron yang topang pada tradisi industri pertelevisian, yaitu efektif dan efesiensi yang didukung standarisasi, konsistensi dalam waktu dan ruang penciptaan maupun penayangan.

Insan sinetron Indonesia hendaknya tidak hanya sekedar melakukan model peniruan sinetron asing atau sinetron Indonesia yang mempunyai rating tinggi. Mereka harus melakukan peniruan yang profesional. Dengan demikian penonton tidak merasa dirugikan. Selain itu, insan sinetron Indonesia harus tidak segan segan melakukan inovasi - inovasi baik dari segi kulitas maupun tema. Kegagalan bukan sebuah kenistaan akan tetapi berani melakukan lompatan dengan menciptakan inovasi- inovasi melalui tali yang rapuh merupakan kerja yang besar akan tetapi akan menghasilkan sesuatu yang besar dan sangat memuaskan.

Dalam mendapatkan karya sineron Indonesia yang berkualitas, maka diadakan apresiasi terhadap baik sinetron maupun tayangan - tayangan televisi yang lain dengan mengadakan gobel award dan apresiasi lainya. Salah satunya adalah diadakannya FSI (Festival Sinetron Indonesia) yang telah berlangsung lima kali yaitu pada tahun 1992, 1994, 1995, 1996, 1997. Pada festifal ni diharapkan tidak sekedar festifal asal asalan, tetapi merupakan sarana apresiasi seluruh masyarakat sinetron dan mampu menggairahkan pesinetron juga insan sinetron diharapka mampu melakukan inovasi- inovasi yang lebih berkualitas.

Pengalaman dunia perfilman Indonesia harus menjadi pelajaran berharga. FFI (Festifal Film Indonesia) yang diadakan setiap tahunnnya tidak lebih sekedar pengumuman atau informasi nominasi semata. Kegiatan ini tidak transparan dalam menentukan indikator penilaian kecuali hanya dewa juri. Para khalayak dan insan perfilman tidak tahu menahu dimana unsur kelebihan bagi pemenang dan dimana unsur kekurangan bagi yang tidak masuk nominasi sehingga tidak jelas karakter ukuran film yang berkualitas maupun tidak. Akibatnya dunia perfilman Indonesia produk filmnya tidak mendapatkan ruang di hati penonton dan masyarakat Indonesia pada umumnya. Lebih buruknya lagi ketika industri perfilman Indonesia mengalami keterpurukan, FFI di Indonesia tidak diselenggarakan lagi.

Selain melalui festifal sinetron, kritik terhadap sinetron dapat dilakukan oleh masyarakat melalui media cetak mauppun media elektronik. Kita mempunyai media cetak yang khusus mengupas program-program hiburan seperti film layar lebar, sinetron maupun tayangan stasiu televisi seperti kompas, surat kabar, majalah. Instragram, whatsapp, BB, face book. Media ini diharapkan dapat menjadi sara komunikasi antara insan sinetron dengan penonton khususnya kritikus sinetron atau film. Melalui media media tersebut kita dapat mengkritik bukan sekedar ringkasan cerita dari sinetron maupun film semata, namun juga dari sisi kehidupan para artis dan juga hobi hobi mereka.

\section{Penutup}

Sinetron Indonesia dalam kurun waktu terahir ini mengalami perkembangan yang sangat menggembirakan. Hal tersebut tidak terlepas dari perkembangan dunia pertelevisian yang sangat pesat. Perkembangan televisi yang semakin pesat ini memberikan ruang dan 
waktu sinetron sinetron Indonesia berkembang pula. Perkembangan ini diperkirakan akan terus meningkat ditahun-tahun mendatang karena UU pokok siaran yang sudah berlaku (BAB. IV pasal 32 ayat 2 menjelaskan bahwa proporsi produksi dalam negeri dan luar negeri adala 70 banding 30. Namun hal ini belum diikuti oleh perkembangan kualitas produksi yang memadai. Efesiensi dan efektifitas waktu masih menjadi kriteria kejar tayang yang laku ditonton dan dipasang iklan. Selain itu ada beberapa hal yang menjadi penyebab sinetron Indonesia kurang berkualitas, yaitu

a. Pengembangan budaya meniru yang kurang profesional

b. Terdapat episode yang jumlahnya ribuan yang berakibat Alur dan tema cerita kurang fokus dan terkadang kehilangan alur cerita pokoknya.

c. Ukuran kualitas sinetron Indonesia terletak pada rating jumlah pemirsa semata

Mengingat fungsi sinetron Indonesia bukan hanya sebagai hiburan semata tetapi sebagai sarana media massa dalam pendidikan, pewarisan dan mengenalkan budaya sosial di Indonesia maka apresiasi terhadap perkembangan sinetron Indonesia harus di tingkatkan. Tanggungjawab pemberdayaan sinetron Indonesia untuk menjadi tuan rumah di rumah sendiri yang terletak pada kepuasan masyarakat Indonesia dalam menikmati tayangan sinetron atau acara tayangan stasiun televisi Indonesia.

\section{Daftar Pustaka}

Basuki, Sinetron Indonesia Antara pertumbuhan dan kecemasan, Jurnal Paradigma Vol I, No. 4, Desember 2017, (Yogyakarta: FISIPOL UPN “Veteran”), 2017

Jalaludin R, Metodologi Penelitian Komunikasi, (Bandung: Rosdakarya), 2000

Jalaludin, R. Psikologi Komunikasi, (Bandung: Rosdakarya), 1990

Jurnal Kajian Bahasa sasra dan pengajaran (KIBASP), 2 (1)- 96:105, 2018

Kuswandi, W. Komunikasi Massa: Sebuah Analisis Media Televisi, (Jakarta: Rineke Cipta), 1996

Mc. Quail, D. Teori Komunikasi Massa: Suatu Pengantar. (Jakarta: Erlangga), 1989

Morissan, Teori komunikasi individu bingga Massa, Jakarta: Prenada Media Group), 2013

Nugroho. G. Kekuasaan dan Hiburan,(Yogyakarta: Yayasan Bintang Budaya),

Stanley J. Baran \& Dennis K. Davis. Mass Comunication Theory (Foundations, Ferment, and Future: Sixth Edition), 2015

Subroto, DS. Produksi Acara Televisi. (Yogyakarta: Duta Wacana University press), 1994.

Suraya, Yulia Yasmasari, Jurnal Prosiding Konferensi Nasional Komunikasi, Vol, 01, no. 01,2017

Teti Milawati, penngkatan kemampuan anak memahami drama dan menulis teks dranma melalui pembelajan SAVI, Jurnal Edisi khusus,no 2 ,Agustus 2017

Wardhana, WS. Kapitalisme Televisi dan Strategi Budaya Massa, (Yogyakarta: Pustaka Pelajar), 1997. 